\title{
SULPHUR CYCLING BETWEEN TERRESTRIAL AGROECOSYSTEM AND ATMOSPHERE*
}

\author{
Željka ZGORELEC ${ }^{1}$, Gordana PEHNEC ${ }^{2}$, Ferdo BAŠIĆ ${ }^{1}$, Ivica KISIĆ' ${ }^{1}$, Milan MESIĆ1, Silva \\ ŽUŽUL ${ }^{2}$, Aleksandra JURIŠŚĆ ${ }^{1}$, Ivana ŠESTAK ${ }^{1}$, Vladimira VAĐIĆ ${ }^{2}$, and Mirjana ČAČKOVIĆ ${ }^{2}$ \\ Faculty of Agriculture, University of Zagreb ${ }^{1}$, Institute for Medical Research and Occupational Health ${ }^{2}$, \\ Zagreb, Croatia
}

Received in April 2012

CrossChecked in August 2012

Accepted in August 2012

\begin{abstract}
Central gas station of the natural gas borehole system Podravina is located near the village Molve. It delivers more than a quarter of total energy used in Croatia to its consumers. Over the years, adapting technology to increasingly demanding and rigorous standards in environmental protection has become paramount. Yet, despite all the industry has undertaken to address the risk of harmful substances entering the food chain, a multidisciplinary research team of independent scientists monitors the content of specific substances in all components of the ecosystem.

This paper presents measurements of total sulphur contents in soil surface [(0 to 3$) \mathrm{cm}]$ and subsurface [(3 to 8) cm] layers (study period: autumn 2006 - spring 2010) and in plants (study period: spring 2000 spring 2010), and the concentration of gaseous sulphur compounds in the air. Concentrations of hydrogen sulphide $\left(\mathrm{H}_{2} \mathrm{~S}\right)$ and mercaptans (RSH) were measured from the summer of 2002 until the autumn of 2010 , while concentrations of sulphur dioxide $\left(\mathrm{SO}_{2}\right)$ were measured from the spring of 2008 until the autumn of 2010. The paper also shows total annual atmospheric sulphur $\left(\mathrm{S}^{-\mathrm{SO}_{4}}\right)$ deposition at Bilogora measuring station (study period: 2001 - 2010). Average monthly concentrations of $\mathrm{H}_{2} \mathrm{~S}$ in air varied between $0.2 \mu \mathrm{g} \mathrm{m}^{-3}$ and $2.0 \mu \mathrm{g} \mathrm{m}^{-3}$, RSH between $0.1 \mu \mathrm{g} \mathrm{m}^{-3}$ and $24.5 \mu \mathrm{g} \mathrm{m}^{-3}$, and $\mathrm{SO}_{2}$ between $0.4 \mu \mathrm{g} \mathrm{m}^{-3}$ and $2.8 \mu \mathrm{g} \mathrm{m}^{-3}$ depending on the location and the season of sampling.

Mean values of total sulphur in soil and in Plantago lanceolata plant ranged between $610 \mathrm{mg} \mathrm{kg}^{-1}$ and $1,599 \mathrm{mg} \mathrm{kg}^{-1}$ and between $3,614 \mathrm{mg} \mathrm{kg}^{-1}$ and $4,342 \mathrm{mg} \mathrm{kg}^{-1}$, respectively, depending on the soil type, location, and sampling depth. Average values of total sulphur mass ratio for all examined single soil samples $(\mathrm{n}=80)$ were $1,080 \mathrm{mg} \mathrm{kg}^{-1}$ for both studied layers, and 4,108 $\mathrm{mg} \mathrm{kg}^{-1}$ for all analysed plant samples $(\mathrm{n}=85)$. Average total annual atmospheric sulphur deposition at Bilogora measuring station was $6.3 \mathrm{~kg}$ of S-SO per hectar.
\end{abstract}

KEY WORDS: air, deposition, $\mathrm{H}_{2} \mathrm{~S}$, mercaptans, Plantago lanceolata, $\mathrm{SO}_{2}$, soil, total sulphur

The northern part of the Pannonian plain in Croatia is a traditional agricultural region [Western Pannonian region according to Bašić et al. (1) ] rich in natural gas. The coexistence of agriculture and energy is

* Partly presented at the $7^{\text {th }}$ Croatian Scientific and Professional Assembly "Air Protection "11" in Šibenik, Croatia, 13-17 September 2011 clearly essential to stakeholders. Central gas station (CGS) of the natural gas borehole system Podravina is located near the village Molve. Natural gas is not a pure product. When gas is extracted from a field under the supercritical conditions (high pressure and temperature) it may contain harmful and corrosive components such as $\mathrm{CO}_{2}, \mathrm{H}_{2} \mathrm{~S}, \mathrm{RHS}, \mathrm{Hg}^{0}$ etc. In CGS, 
natural gas is collected, treated, purified, and distributed to consumers. For the past 21 years, the scientists within a multidisciplinary research team have monitored its influence on air, water, soil, plants, forests, animals (wild and domestic), as well as humans. Since 1991, the Institute for Medical Research and Occupational Health, Zagreb (Environmental Hygiene Unit) has been in charge of the environment and air quality monitoring on carefully selected representative locations in CGS, while the soil and plant quality monitoring has been the task of the Faculty of Agriculture, University of Zagreb (Department of General Agronomy).

In the past, all pollutants from different industrial sources were emitted in the atmosphere. As landowners became more aware of the ecological and health problems, they insisted on some improvements. As a result, some technological processes were modified, such as the installation of two mercury $(\mathrm{Hg})$ absorbers using active carbon impregnated with sulphur, LOCAT unit $\left(\mathrm{H}_{2} \mathrm{~S}\right.$ oxidation in elementary $\left.\mathrm{S}\right)$, and RTO unit (oxidation of reduced sulphur compounds to $\mathrm{SO}_{2}$ ). Despite all the measures that were taken to protect the environment and local public health, it was still necessary to establish a quality multidisciplinary monitoring programme since only independently collected scientific data could provide relevant information for conclusions and possible solutions for the environment protection.

Sulphur is a biogeoelement in agroecosystem and a macronutrient for plants, as well as a constituent of certain essential amino acids, vitamins, enzymes, and aromatic oils. Sulphur deficient plants tend to have low sugar but high nitrate content in their sap and leaf chlorosis, which can cause lower yield and lower plant quality $(2,3)$. But high concentrations of $S$ in soil or air can be toxic to plants, animals, and humans (4-6). The three major natural sources of sulphur that can be available for plant uptake are (1) organic matter; (2) soil minerals; and (3) sulphur gases in the atmosphere (7).

According to Deloch (8), natural total sulphur content range is different in grasses (corn 1,700 $\mathrm{mg} \mathrm{kg}^{-1}$ of dry matter (DM), barley 1,800 $\mathrm{mg} \mathrm{kg}^{-1}$ of DM), legumes (bean 2,400 mg kg-1 of DM, soybean 3,200 mg kg-1 of DM) and cruciferae (rape $10,000 \mathrm{mg} \mathrm{kg}^{-1}$ of DM, radicchio 17,000 of DM). Some authors have studied the influence of atmospheric sulphur $\left(\mathrm{SO}_{2}\right.$ and $\left.\mathrm{H}_{2} \mathrm{~S}\right)$ from different anthropogenic sources, mostly power plants, on soil and the uptake in some plant species. Reimann etal. (9) measured total sulphur concentrations in some plants from different catchments in northern
Europe and one location near the nickel smelter and refinery. They found the median S concentration of $965 \mathrm{mg} \mathrm{kg}^{-1}$ in moss; $990 \mathrm{mg} \mathrm{kg}^{-1}$ in conifers; $1,490 \mathrm{mg} \mathrm{kg}^{-1}$ in shrubs; and $1,900 \mathrm{mg} \mathrm{kg}^{-1}$ in deciduous trees with significantly higher concentrations observed on a polluted location. In a field study conducted in the vicinity of two thermal power plants in India, Agrawal et al. (10) noted a high correlation between the emission from power plants and elemental concentrations of sulphur in the leaves of evergreen and deciduous plants (significantly higher concentrations on polluted than on unpolluted sites). Fidalgo-Hijano et al. (11) obtained the following results in a study conducted in the city of Madrid on different plants as bioindicators of sulphur emission: a higher accumulation of sulphur was found in vegetable species located near highways and dense traffic roads and near the areas with high population density. The minimal accumulation of $\mathrm{SO}_{2}$ was registered in winter and spring seasons (from January to April) due to the end of vegetative growth, while maximal values were recorded during the summer season (from June to September), due to stomatal opening. Regarding sulphur in agroecosystem, our team has already studied sulphur behaviour in central Croatia through field experiments on an unpolluted site and has published data related to sulphur wheat grain uptake depending on the fertilisation (12) and $\mathrm{S}^{-\mathrm{SO}_{4}}$ losses from soil with drainage water (13).

The goal of this paper is to study sulphur cycling between terrestrial agroecosystem and atmosphere and to present the results of measurements of total sulphur content in soils, total sulphur content in plants, concentration of gaseous sulphur compounds $\left(\mathrm{H}_{2} \mathrm{~S}\right.$, $\mathrm{RSH}, \mathrm{SO}_{2}$ ) in air, and annual atmospheric sulphur $\left(\mathrm{S}_{-} \mathrm{SO}_{4}\right)$ deposition measured during the monitoring that was carried out over several years in the vicinity of CGS Molve.

\section{MATERIAL AND METHODS}

Samples of air, soil, and plants were collected at four locations in the vicinity of boreholes Molve 9 (M9), Molve 10 (M10), Molve 11 (M11), and Molve 12 (M12). Geographic locations of sampling sites in the area of CGS Molve were described and summarised in our previous study (14) regarding arsenic in soil and air measured in the surroundings of CGS Molve. 


\section{Air sampling and analysis}

Measurements of $\mathrm{H}_{2} \mathrm{~S}, \mathrm{RSH}$, and $\mathrm{SO}_{2}$ concentrations in air were done twice a year, in a 30-day period during the warmer season (summer time) and a 30-day period during the colder season (winter or early spring or late autumn). Samples of $\mathrm{H}_{2} \mathrm{~S}$ and $\mathrm{RSH}$ were collected during 24 hours by forcing the air to the filter paper Whatman No. 41 impregnated with mercury(II) chloride with the addition of urea as an antioxidant $\left(\mathrm{H}_{2} \mathrm{~S}\right)$ and mercury(II) acetate with the addition of acetic acid (RSH). Analysis of $\mathrm{H}_{2} \mathrm{~S}$ was carried out spectrophotometrically by molybdenum blue method $(15,16)$. Mercaptans were also determined spectrophotometrically after adding $N, N$-dimethyl-pphenylenediamine hydrochloride and Reissner reagens (17). Samples of $\mathrm{SO}_{2}$ were collected by forcing air through the absorption solution of hydrogen peroxide (18) and the resulting concentration of sulfate ions was determined by ion chromatography (19). The analysis was performed on Dionex DX 120 chromatograph equipped with suppressed conductivity detection, Dionex AS14 analytical column, and AG14 guard column. The eluent was $3.5 \mathrm{mmol} \mathrm{L}^{-1} \mathrm{Na}_{2} \mathrm{CO}_{3} /$ $1 \mathrm{mmol} \mathrm{L}^{-1} \mathrm{NaHCO}_{3}$ solution.

This paper presents average monthly mass concentrations of gaseous sulphur compounds $\left(\mathrm{H}_{2} \mathrm{~S}\right.$, $\mathrm{RSH}$, and $\mathrm{SO}_{2}$ ) in air during the study period of summer 2002 - autumn $2010\left(\mathrm{H}_{2} \mathrm{~S}\right.$ and $\left.\mathrm{RSH}\right)$ and during the study period of autumn 2008 - autumn 2010 $\left(\mathrm{SO}_{2}\right)$. Generally, the measured concentrations were very low, and sometimes even below the limit of detection of the used method.

\section{Soil and plant sampling and analysis}

Soil and plant samples were collected twice a year, in spring and autumn, on four locations in the vicinity of the above mentioned boreholes. Surface [ 3 to 8) $\mathrm{cm}]$ and subsurface soil samples [(3 to 8$) \mathrm{cm}]$ were taken with a Holland probe and a knife following the Protocols of soil sampling (20). Plant samples were also collected with a knife. Ribwort Plantain (Plantago lanceolata L.) plant (leaves and stems) was gathered as an indicator. In the borehole M9 area, soil and plant samples were collected for two different types of soil (locations M9 and M9 hill). All examined locations included five soil types, dominant in respect of their texture and moisture regime: according to Croatian classification (21) they are classified as: M9 and M12: Eugley, M9 hill: Distric Regosols, M10: Stagnic Luvisols and M11: Gleysols or According to the World
Reference Base (WRB) for soil resources (22): M9: Gleysol vertic dystric and M9 hill: Regosol acric, M12: Gleysol vertic, M10: Stagnosol luvic and M11: Gleysols clayic. According to their texture, two of them belong to heavy clay soils (M9 and M12), two to silt loam soil (M10 and M11), and one to light sandy soils (M9 hill).

Soil samples were air-dried, ground, sieved $(<2 \mathrm{~mm})$ and homogenised according to the ISO Protocol (23). Plant samples were first dried in the oven at $105^{\circ} \mathrm{C}$ until a constant mass was reached, and were then ground and homogenised.

Analyses of Plantago laceolata samples and soil samples on total sulphur content were done by elementary analyser Vario Macro CHNS, Elementar, Deutschland, 2006 following the ISO Protocol (24).

Accuracy and precision were controlled by Reference Material (RM: ISE and IPE, Wepal) and by repeating the same sample measurements, respectively. Accuracy and precision limits were determined within the standards and were acceptable.

This paper presents measurements of total sulphur mass ratio in soil, in surface and subsurface layers (study period: autumn 2006 - spring 2010), as well as in plants (study period: spring 2000 - spring 2010).

The paper also shows total annual atmospheric sulphur $\left(\mathrm{S}_{-} \mathrm{SO}_{4}\right)$ deposition at Bilogora measuring station (study period: 2001 - 2010) (25).

\section{RESULTS AND DISCUSSION}

\section{Sulphur components in air}

Monthly average mass concentrations of $\mathrm{H}_{2} \mathrm{~S}$ for each measuring period measured in CGS surroundings are presented in Figure 1. Monthly average concentrations of $\mathrm{H}_{2} \mathrm{~S}$ in air varied between $0.2 \mu \mathrm{g}$ $\mathrm{m}^{-3}$ (spring 2006) and $2.0 \mu \mathrm{g} \mathrm{m}^{-3}$ (summer 2002), and the maximal daily value $\left(6.6 \mu \mathrm{g} \mathrm{m}^{-3}\right)$ was measured during the summer of 2009. According to Croatian legislation, in particular the Regulation on Limit Values of Pollutants in Air (26), the limit values (LVs) for $\mathrm{H}_{2} \mathrm{~S}$ in air are $2 \mu \mathrm{g} \mathrm{m}^{-3}$ (for an average time of one year) and $5 \mu \mathrm{g} \mathrm{m}^{-3}$ (for a 24-hour collecting period, but LVs may not be exceeded more than seven times during a calendar year). The results cannot be compared with the LV (for one year) because we performed measurements only 60 days per year which is only $17 \%$ of all data; however, they could be 
indicative. During the examination period, the measured values (average daily concentrations) exceeded LV $\left(5 \mu \mathrm{g} \mathrm{m}^{-3}\right)$ three times in 2002 , and once in 2004, 2009, and 2010.

Monthly average mass concentrations of RSH for each examination period measured in CGS surroundings are presented in Figure 2. These varied between $0.1 \mu \mathrm{g} \mathrm{m}^{-3}$ (winter 2006) and $24.5 \mu \mathrm{g} \mathrm{m}^{-3}$ (summer 2005), and the maximal daily value measured was $89.2 \mu \mathrm{g} \mathrm{m}^{-3}$. According to national legislation (26), LVs for RSH in air are $1 \mu \mathrm{g} \mathrm{m}^{-3}$ (for an average time of one year) and $3 \mu \mathrm{g} \mathrm{m}^{-3}$ (for a 24 -hour collecting period, but LVs may not be exceeded more than seven times during a calendar year). As we can see in Figure 2, in the period from 2002 until 2006, mass concentrations of RSH were frequently higher than $3 \mu \mathrm{g} \mathrm{m}^{-3}$ while in the period from 2007 until 2010, the limit value of $3 \mu \mathrm{g} \mathrm{m}^{-3}$ was not exceeded. In the period from 2002 until 2006, there were a number of days with daily concentrations of RSH higher than $3 \mu \mathrm{g}$ $\mathrm{m}^{-3}$. There were months when only one day per month exceeded the LV (at M9, M10, and M12 in summer 2002 and at M12 in summer 2005), but there were also months where all 30 daily measured values were higher than $3 \mu \mathrm{g} \mathrm{m}^{-3}$ (at M11 in summer 2004 and at M10 in summer 2005). In 2007, a system for burning waste gases was built in CGS Molve (RTO unit oxidation of reduced sulphur components to $\mathrm{SO}_{2}$ ), which is a probable reason for such a decrease in the $\mathrm{RSH}$ content in air.

Monthly average mass concentrations of $\mathrm{SO}_{2}$ for each measuring period observed in air in CGS surroundings are presented in Figure 3. These were very low and ranged between $0.4 \mu \mathrm{g} \mathrm{m}^{-3}$ (at M11, in summer 2005) and $2.8 \mu \mathrm{g} \mathrm{m}^{-3}$ (at M10, in summer 2010) depending on the location and the season of sampling, while the maximal daily value $\left(9.3 \mu \mathrm{g} \mathrm{m}^{-3}\right)$ was measured during the autumn of 2009. According

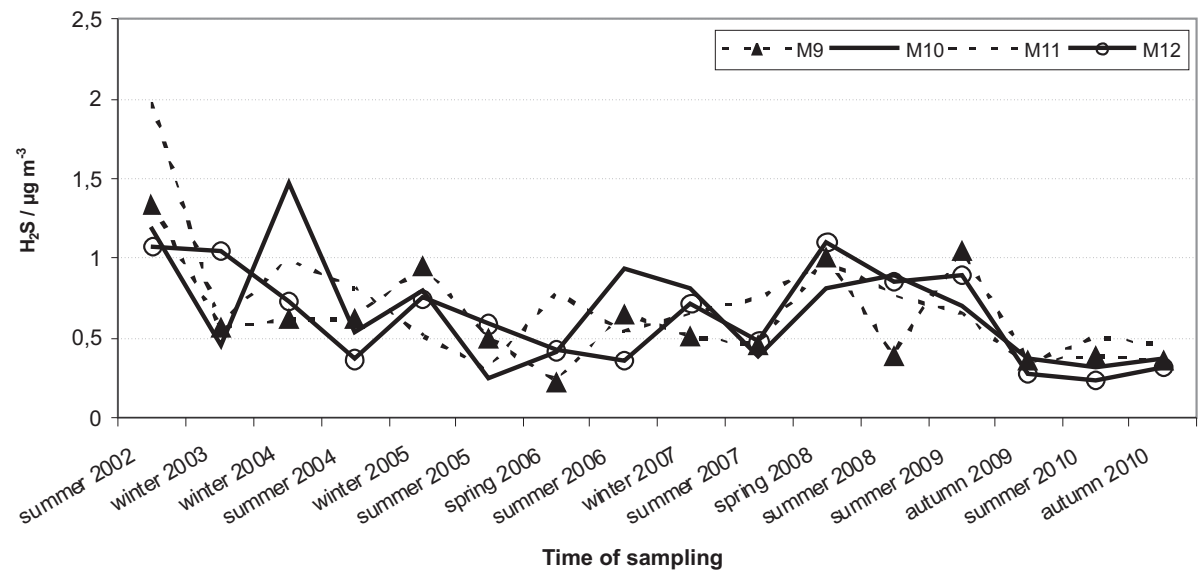

Figure 1 Average monthly concentration of $\mathrm{H}_{2} \mathrm{~S}$ measured in air in central gas station (CGS) surroundings

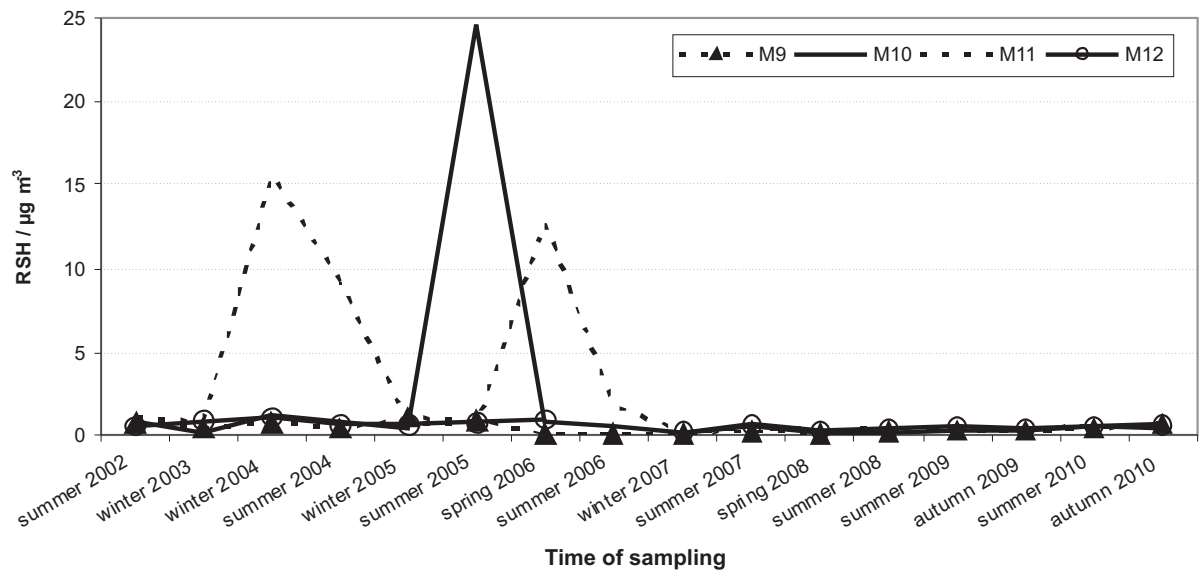

Figure 2 Average monthly concentration of RSH measured in air in central gas station CGS surroundings 


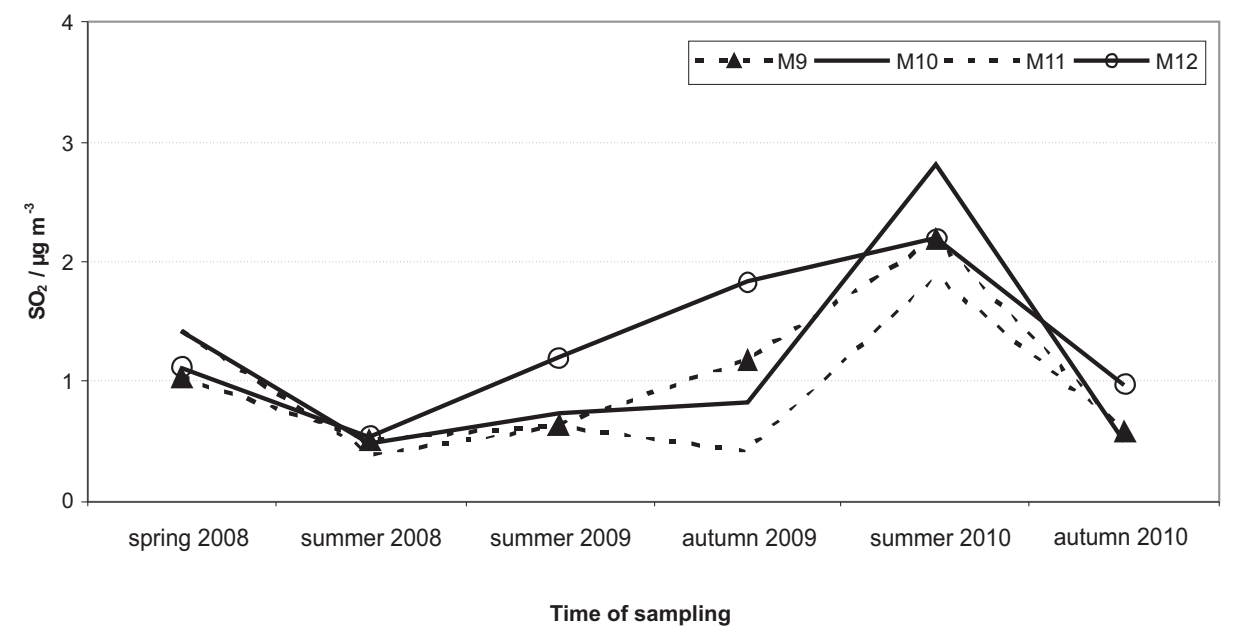

Figure 3 Average monthly concentration of $\mathrm{SO}_{2}$ measured in air in central gas station (CGS) surroundings

to national legislation (26), $\mathrm{LVs}$ for $\mathrm{SO}_{2}$ in air are $50 \mu \mathrm{g} \mathrm{m}^{-3}$ (for an average time of one year) and $125 \mathrm{\mu g} \mathrm{m}^{-3}$ (for a 24-hour collecting period, but LVs may not be exceeded more than seven times during a calendar year). During the study period, the LV $\left(125 \mu \mathrm{g} \mathrm{m}^{-3}\right)$ was not exceeded. Considering the fact that the investigated area is relatively unpopulated, it is relevant to mention that national legislation (26) also prescribes $\mathrm{LV}$ s for the concentration of pollutants $\left(\mathrm{SO}_{2}\right.$ and $\left.\mathrm{NO}_{\mathrm{x}}\right)$ in air for the protection of ecosystem and vegetation. For $\mathrm{SO}_{2}, \mathrm{LV}$ in air is $20 \mu \mathrm{g} \mathrm{m}^{-3}$ (for an average time of one calendar year and winter period), which is still high above the observed values in our study.

\section{Sulphur in soil}

Total sulphur mass ratio measured in surface $[(0$ to 8$) \mathrm{cm}$ ] and subsurface [( 3 to 8$) \mathrm{cm}$ ] soil layers for each measuring period in CGS surroundings is shown in Figures 4 and 5, respectively.

According to Isaac and Kerber (27), normal concentration range of total $\mathrm{S}$ in soils is $500 \mathrm{mg} \mathrm{kg}^{-1}$ to $4,000 \mathrm{mg} \mathrm{kg}^{-1}$. Total $\mathrm{S}$ in mineral soils may range from $<20 \mathrm{mg} \mathrm{kg}^{-1}$ in sandy soils to $>600 \mathrm{mg} \mathrm{kg}^{-1}$ in heavy texture soils. Organic soils may contain as much as $5,000 \mathrm{mg} \mathrm{kg}^{-1}$. Moist soils, however, contain sulphur between $100 \mathrm{mg} \mathrm{kg}^{-1}$ and $500 \mathrm{mg} \mathrm{kg}^{-1}$ (28).

In a study conducted in the USA on Alberta soil samples $(\mathrm{n}=18)$, total sulphur content in different soil

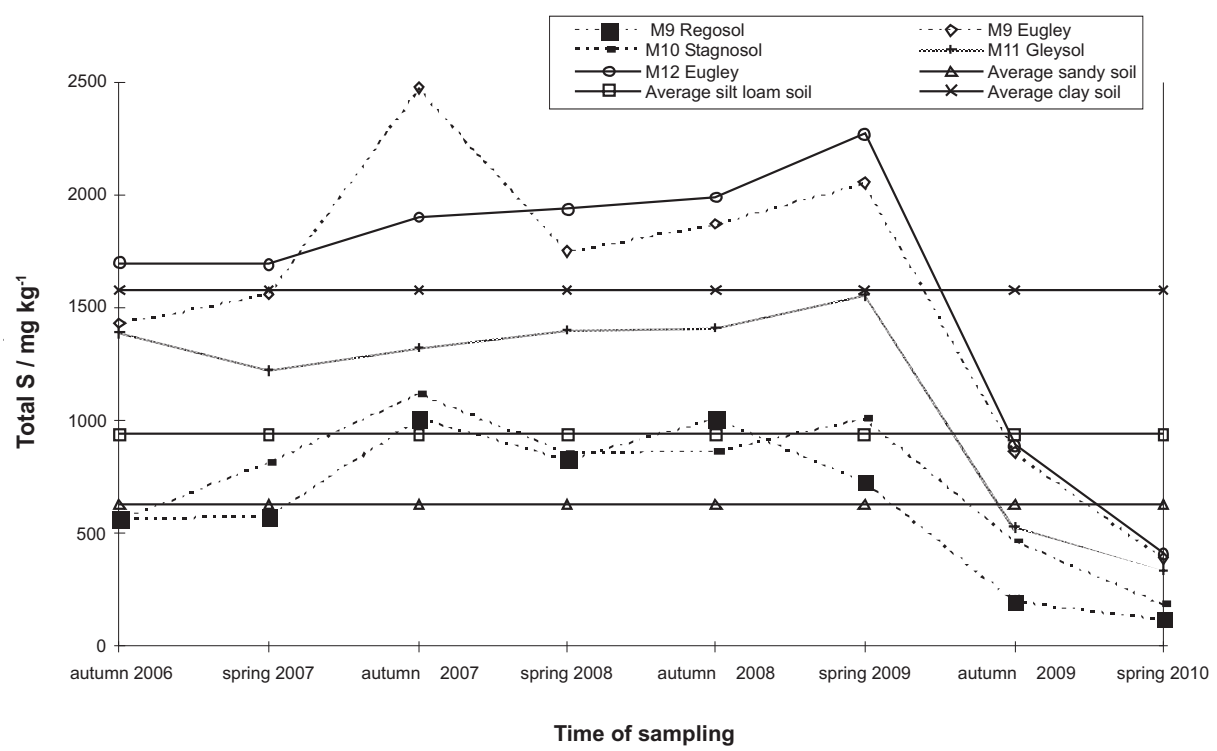

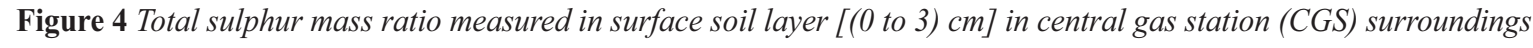




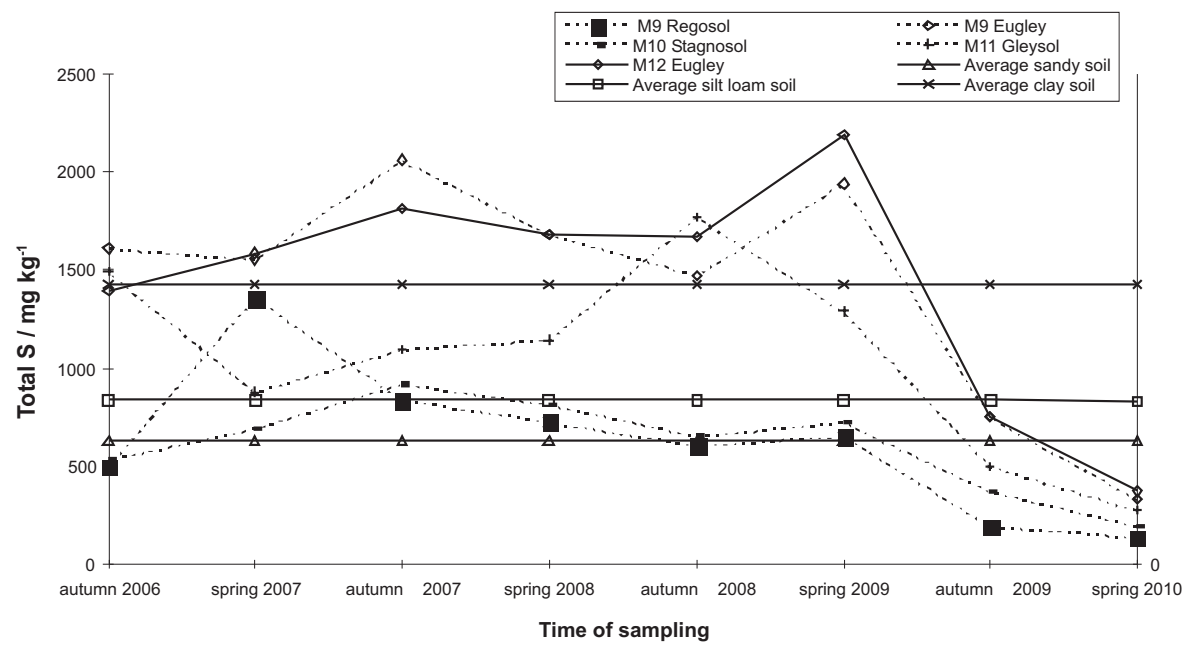

Figure 5 Total sulphur mass ratio measured in subsurface soil layer [(0 to 3) cm] in central gas station (CGS) surroundings

types in surface horizon were: up to $343 \mathrm{mg} \mathrm{kg}^{-1}$ in humic eluviated gleysol (lacustrine) in (0 to 10$) \mathrm{cm}$; up to $869 \mathrm{mg} \mathrm{kg}^{-1}$ in orthic humic gleysol (lacustrine) in (0 to 12$) \mathrm{cm}$; and up to $1,040 \mathrm{mg} \mathrm{kg}^{-1}$ in humic eluviated gleysol (till) in (0 to 3) $\mathrm{cm}$ (29).

In our case, mean values of total sulphur in soil ranged between $610 \mathrm{mg} \mathrm{kg}^{-1}$ observed on Stagnosol (M10) in subsurface horizon and $1,599 \mathrm{mg} \mathrm{kg}^{-1}$ measured on Eugley (M12) in surface horizon. For all examined periods, from autumn 2006 until spring 2010 , single values of total sulphur in soil ranged between minimal $120 \mathrm{mg} \mathrm{kg}^{-1}$ measured on Regosol (M9 hill) in surface horizon in spring 2010 and maximal 2,470 mg kg-1 measured on Eugley (M 9) also in surface horizon in autumn 2007. Average values measured for sandy $(\mathrm{n}=8)$, silt loam $(\mathrm{n}=16)$, and clay $(\mathrm{n}=16)$ soils were in surface soil layer $631 \mathrm{mg} \mathrm{kg}^{-1}$, $941 \mathrm{mg} \mathrm{kg}^{-1}$, and $1,573 \mathrm{mg} \mathrm{kg}^{-1}$ and in subsurface soil layer $625 \mathrm{mg} \mathrm{kg}^{-1}, 832 \mathrm{mg} \mathrm{kg}^{-1}$, and 1,426 $\mathrm{m} \mathrm{kg}^{-1}$, respectively. Furthermore, the average values of all examined single samples $(n=40)$ in surface and subsurface soil layers, were $1,132 \mathrm{mg} \mathrm{kg}^{-1}$ and $1,028 \mathrm{mg} \mathrm{kg}^{-1}$, respectively. We observed a slightly lower mass ratio of total sulphur in deeper horizons (Figures 4 and 5) and an increasing trend of total S with a decrease in soil particle size (sandy $<$ silt loam $<$ clay).

\section{Sulphur in plants}

Total sulphur mass ratio recorded in Ribwort Plantain for each measuring period in CGS surroundings is shown in Figure 6.
According to Isaac and Johnson (30), normal concentration ranges of total $\mathrm{S}$ in plant tissue are between $500 \mathrm{mg} \mathrm{kg}^{-1}$ and 20,000 $\mathrm{mg} \mathrm{kg}^{-1}$.

Mean values of total sulphur in Plantago lanceolata ranged between $3,614 \mathrm{mg} \mathrm{kg}^{-1}$ measured in the plant grown on Stagnosol (M10) and 4,342 $\mathrm{mg} \mathrm{kg}^{-1}$ measured in the plant grown on Eugley (M12).

Single values for all examined periods, from spring 2000 until spring 2010, for total sulphur in the plant were between minimal $1,910 \mathrm{mg} \mathrm{kg}^{-1}$ measured in the plant grown on Gleysol (M11) in spring 2000 and maximal $8,040 \mathrm{mg} \mathrm{kg}^{-1}$ measured in the plant grown on the same location and the same soil type on Gleysol (M 11) but in autumn 2008.

Average values observed in Plantago lanceolata grown on sandy $(\mathrm{n}=17)$, silt loam $(\mathrm{n}=34)$, and clay $(\mathrm{n}=34)$ soils where 4,184 $\mathrm{mg} \mathrm{kg}^{-1}, 3,967 \mathrm{mg} \mathrm{kg}^{-1}$, $4,212 \mathrm{mg} \mathrm{kg}^{-1}$, respectively. Furthermore, the average values of total sulphur mass ratio for all examined single plant samples $(\mathrm{n}=85)$ were $4,108 \mathrm{mg} \mathrm{kg}^{-1}$ (Figure 6). As we already mentioned in the Introduction, according to Deloch (8), natural total sulphur content varies in different plants, depending on the plant species and cultivar; for example, in grasses like barley its content can be $1,800 \mathrm{mg} \mathrm{kg}^{-1}$ of DM, in legumes like soybean $3,200 \mathrm{mg} \mathrm{kg}^{-1}$ of DM and in cruciferae like rape as much as $10,000 \mathrm{mg} \mathrm{kg}^{-1}$ of DM (Figure 6). We observed an increasing trend in sulphur mass ratio in Plantago lanceolata over the years (from spring 2000 until spring 2010). The correlation was positive and ranged from medium to strong depending on the soil type, but we cannot connect this increase only and exclusively with the CGS Molve. 


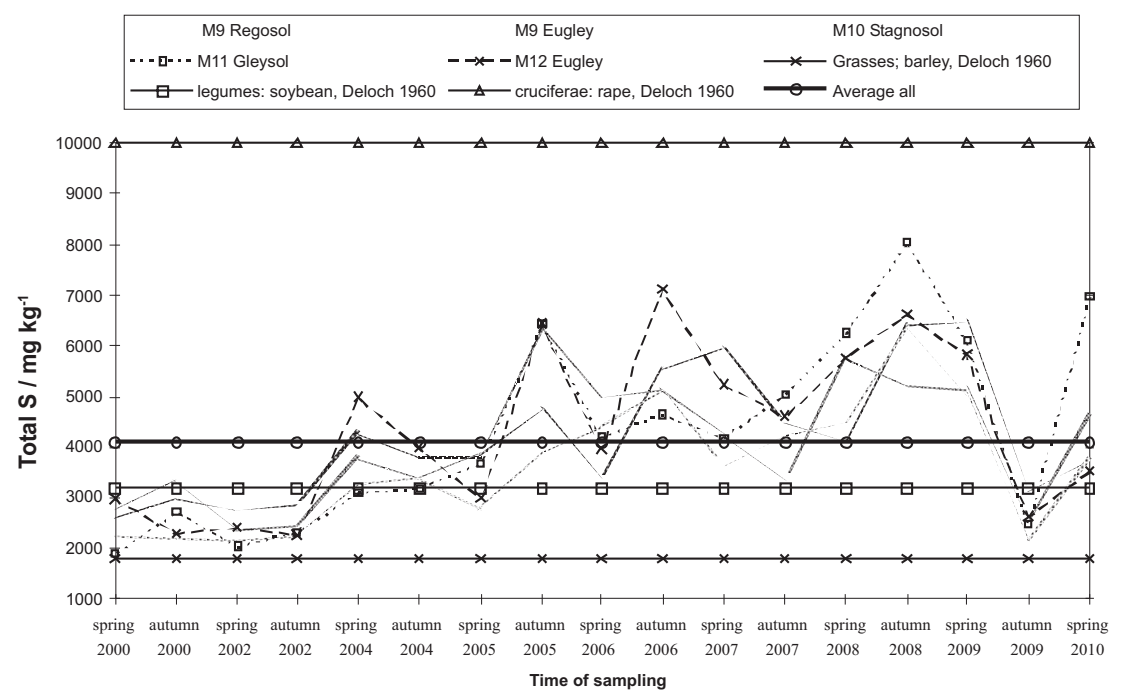

Figure 6 Total sulphur mass ratio measured in Ribwort Plantain (Plantago lanceolata) in central gas station (CGS) surroundings

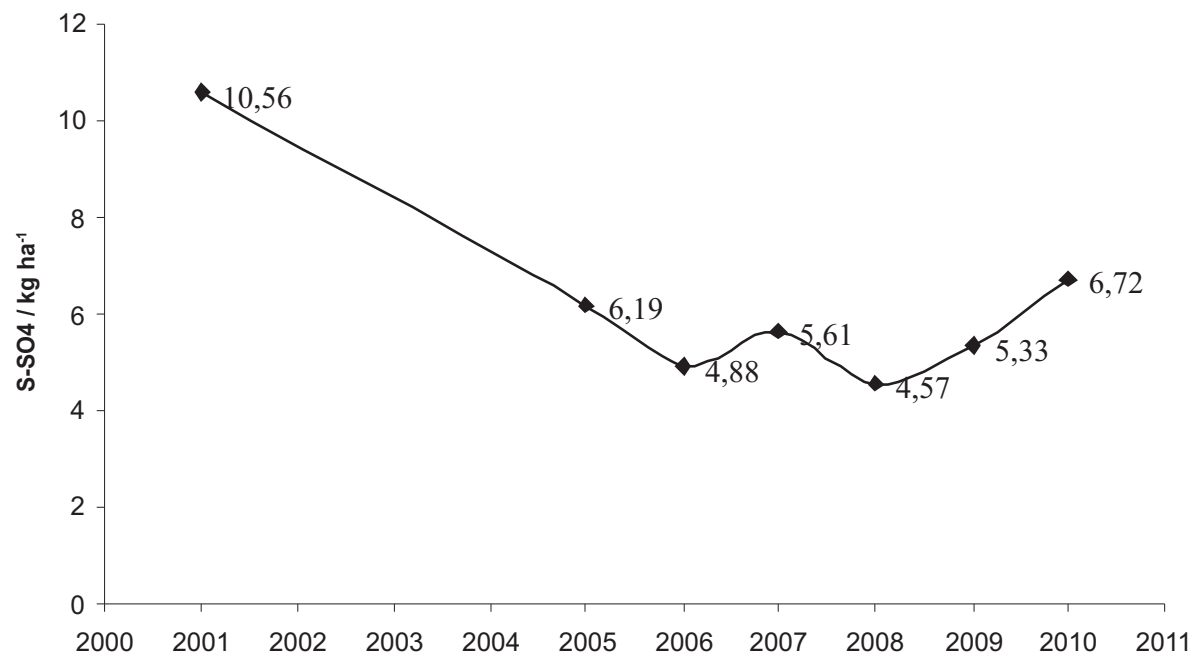

Figure 7 Annual atmospheric total sulphur depositions at Bilogora measuring station; data from Central Bureau of Statistics RH, Statistical Yearbooks of Republic of Croatia (2001-2011), Meteorological and Hydrological Service

\section{Sulphur deposition and sulphur plant requirements}

Annual atmospheric total sulphur deposition at Bilogora measuring station for the period 2001 through 2010 is presented in Figure 7 (25). This value ranged from $4.57 \mathrm{~kg} \mathrm{ha}^{-1}$ (2008) up to $10.56 \mathrm{~kg} \mathrm{ha}^{-1}$ (2001), the average deposition of $\mathrm{S}^{-\mathrm{SO}_{4}}$ being $6.3 \mathrm{~kg}$ $\mathrm{ha}^{-1}$. Nowadays in eastern North America, annual S deposition is more commonly below (8 to 10 ) $\mathrm{kg} \mathrm{ha}^{-1}$, due to the aplication of clean technology which is more energy efficient than the clasical industrial technology. The latter is still used in industrial China and India, where coal and oil burning cause as much as (50 to 75$) \mathrm{kg} \mathrm{ha}^{-1}$ of sulphur fall level per year, while also in these countries, but in areas with no industry, deposition of $\mathrm{S}$ is generally as small as (1 to 5$) \mathrm{kg}$ $\mathrm{ha}^{-1}(7)$. The total $\mathrm{S}$ requirement in different crops depends on plant material production and crop species. Crops with high production of organic material, protein rich crops or cruciferae have a higher demand for S, for example $50 \mathrm{~kg} \mathrm{ha}^{-1}$ for sugarbeet or cabbage. For this reason, they respond most sensitively to an inadequate $\mathrm{S}$ supply. Other crops have relatively low requirements for $\mathrm{S}$, about $3 \mathrm{~kg} \mathrm{ha}^{-1}$ for barley or wheat grain, for instance (5).

According to our previous studies and regarding sulphur in agroecosystem, we observed that the sulphur uptake in winter wheat grain increased on drained Stagnosol in central Croatia from $6.1 \mathrm{~kg} \mathrm{ha}^{-1}$ 
up to $16.9 \mathrm{~kg} \mathrm{ha}^{-1}(12)$ and $\mathrm{S}-\mathrm{SO} 4$ losses from soil with drainage water increased from $10.6 \mathrm{~kg} \mathrm{ha}^{-1}$ to $15.2 \mathrm{~kg} \mathrm{ha}^{-1}(13)$ depending on different nitrogen fertilisation doses that were applied.

Considering that sulphur is one of 17 plant nutrients (31) that are essential to the growth and development of all plants, it plays a key role in plant health. Losses (plant removal and leaching) and gains (precipitation) of sulphur in agroecosystem are usually in deficit, thus sulphur deficiencies can only be and usually are corrected by the application of an $\mathrm{S}$ fertiliser.

\section{CONCLUSION}

We have not observed elevated levels of sulphur compounds or its potential or mutual association with industrial activity for total sulphur in soil and total sulphur in the examined plant material Ribwort Plantain (Plantago lanceolata L.), but we have observed an increasing trend in sulphur mass ratio in Plantago lanceolata during the study period (from the spring of 2000 until the spring of 2010).

The concentrations of $\mathrm{SO}_{2}$ and $\mathrm{H}_{2} \mathrm{~S}$ in air were generally low for the whole examined period.

Concentrations of RSH in air were relatively high by 2006 and often exceeded the limit daily value $\left(\mathrm{LV}=3 \mu \mathrm{g} \mathrm{m}^{-3}\right)$, but then ensued a period in which measured values were below the limit daily value. The most likely reason for this kind of RSH behaviour and abundance in air was the installation of the equipment for the incineration of waste gases (RTO units).

We definitely recommend further monitoring.

\section{Acknowledgement}

This paper was done within the framework of a multidisciplinary project entitled "Ecosystem Monitoring in Environment of Central Gas Station Molve". The authors would especially like to thank the National Institute of Public Health (Koprivničkokriževačka County) as a coordinator of this demanding project and the Oil and Gas Company (INA) for a complete and active cooperation. Of course, many thanks go to all those who participated in this project, for their hard work and professionalism.

\section{REFERENCES}

1. Bašić F, Bogunović M, Božić M, Husnjak S, Jurić I, Kisić I, Mesić M, Mirošević N, Romić D, Žugec I. Regionalisation of Croatian agriculture. Agric Conspec Sci 2007;72: 27-38.
2. Laegreid M, Bockman OC, Kaarstad O. Agriculture, Fertilizers and Environment. Oslo: CABI Publishing; 1999.

3. Marschner H. Mineral Nutrition of Higher Plants. $2^{\text {nd }}$ ed. San Diego (CA): Academic Press; 1998.

4. Saalbach E. The significance of atmospheric sulfur compounds for the supply of agricultural crops. Angew Bot 1984;58:147-56.

5. Mengel K, Kirkby EA. Principles of Plant Nutrition. $4^{\text {th }}$ ed. Bern: International Potash Institute; 1987.

6. Bergmann W. Nutritional Disorders of Plants, Development, Visual and Analytical Diagnosis. Jena: Gustav Fischer; 1992.

7. Brady NC, Weil RR. Elements of the Nature and Properties of the Soils. New Jersey (USA): Prentice Hall; 2010.

8. Deloch WH. Analytical determination of sulfur in biochemical materials and the uptake of sulfur by crops in relation to fertilizer application $[\mathrm{PhD}$ thesis]. Giessen: Justus Liebig Fakultät Giessen; 1960.

9. Reimann C, Koller F, Frengstad B, Kashulina G, Niskavaara $\mathrm{H}$ and Englmaier P. Total sulfur in leaves of several plant species from nine catchments within a $1500000 \mathrm{~km}^{2}$ area in northern Europe: Local vs. regional variability. Geochem Explor Environ Anal 2003;3:205-15.

10. Agrawal M, Singh J. Impact of coal power plant emission on the foliar elemental concentrations in plants in a low rainfall tropical region. Environ Monit Assess 2000;60:26182.

11. Fidalgo Hijano C, Pettit Domínguez MD, García Giménez R, Hungría Sánchez P, Sancho García I. Higher plants as bioindicators of sulfur dioxide emissions in urban environments. Environ Monit Assess 2005;111:75-88.

12. Jurišić A, Mesić M, Zgorelec Ž, Vuković I. Sulfur balance at different nitrogen fertilization levels. Cereal Res Commun 2008;36(Part 2, Suppl. 5):1211-4.

13. Mesić M, Kisić I, Bašić F, Butorac A, Zgorelec Ž, Gašpar I. Losses of $\mathrm{Ca}, \mathrm{Mg}$ and $\mathrm{SO}_{4}{ }^{2-} \mathrm{S}$ with drainage water at fertilisation with different nitrogen rates. Agric conspec sci 2007;72:153-8.

14. Žužul S, Zgorelec Ž, Bašić F, Kisić I, Mesić M, Vađić V, Orct T. Arsenic in air and soil in the vicinity of the central gas station Molve, Croatia. Bulletin Environ Contam Toxicol 2011;86:501-5

15. Vađić V, Gentilizza M, Hršak J, Fugaš M. Determination of hydrogen sulphide in the air. Staub Reinhalt Luft 1980;40:73

16. Vađić V. [Metoda za određivanje vodik-sulfida u atmosferi, in Croatian]. Zašt Atm 1982;10:116.

17. Moore HBA, Helwig HL, Graul RJ. A spectrophotometric method for the determination of mercaptans in Air. Am Ind Hyg Assoc J 1960;21:466-70.

18. International Organization for Standardization (ISO). ISO 4219:1979 Air quality: Determination of gaseous sulfur compounds in ambient air, Sampling equipment. Geneva: ISO; 1979.

19. United Nations Environment Programme and World Health Organization (UNEP/WHO). Passive and active sampling methodologies for measurement of air quality. Nairobi: UNEP; 1994

20. International Organization for Standardization (ISO). ISO 10381 (Part 1-8): Soil quality: Sampling. Geneva: ISO; 2002-2006 
21. Škorić A, Filipovski G, Ćirić M. [Klasifikacija zemljišta Jugoslavije, in Bosnian/Serbian/Croatian]. Sarajevo: Akademija nauka i umjetnosti Bosne i Hercegovine; 1985.

22. Food and Agriculture Organization of the United Nations (FAO). World reference base for soil resources (WRB). A framework for international classification, correlation and communication. World Soil Resources Reports 103. Rome: FAO; 2006.

23. International Organization for Standardization (ISO). ISO 11464:2004 Soil quality: Pretreatment of samples for physico-chemical analysis. Geneva: ISO; 2004.

24. International Organization for standardization (ISO). ISO 15178:2005 Soil quality: Determination of total sulfur by dry combustion. Geneva: ISO; 2005.

25. Central Bureau of Statistics RH (CBS RH). Statistical Yearbooks of Republic of Croatia, Meteorological and Hydrological Service. Zagreb: CBS RH; 2001-2011.

26. Uredba o graničnim vrijednostima onečišćujućih tvari u zraku [Regulation on Limit Values of Pollutants in Air, in Croatian]. Narodne novine 133/2005.

27. Isaac RA, Kerber JD. Atomic absorption and flame photometry: Techniques and uses in soil, plant, and water analysis. In: Walsh LM, editor. Instrumental methods for analysis of soils and plant tissue. Madison (WI): ASA-CSSASSSA; 1971. p. 18-37.

28. Tabatabai MA. Sulfur. In: Sparks LD, editor. SSSA Book series 5: Methods of soil analysis, Part 3 - Chemical methods. Madison (WI): SSSA-ASA; 1996. p. 921-60.

29. Bremner JM, Tabatabai MA. Use of automated combustion techniques for total carbon, total nitrogen, and total sulfur analysis of soils. In: Walsh LM, editor. Instrumental methods for analysis of soils and plant tissue. Madison (WI): ASACSSA-SSSA; 1971. p. 1-16.

30. Isaac RA, Johnson WC Jr. Determination of sulfur in plant tissue by combustion. In: Isaac RA, Johnson WC, editor. Methodology for the analysis of soil, plant, feed, water and fertilizer samples. Athens (GA): Cooperative Extension Service, Soil Testing and Plant Analysis Laboratory, University of Georgia; 1984; p. 92-3.

31. Tandon HLS. Sulfur in Soils, Crops and Fertilizers from Research to Practical application. New Delhi: Viba Press; 2011. 


\section{Sažetak}

\section{KRUŽENJE SUMPORA IZMEĐU TERESTRIČKOG AGROEKOSUSTAVA I ATMOSFERE}

Centralna plinska stanica plinskobušotinskog sustava Podravina nalazi se u Molvama, a potrošačima energije isporučuje više od četvrtine ukupne energije koja se troši u Hrvatskoj. Prilagodba tehnologije sve zahtjevnijim i strožim standardima zaštite okoliša tijekom godina bila je neupitna, no bez obzira na sve učinjeno od strane industrije, a s obzirom na rizik ulaska štetnih tvari u hranidbeni lanac, u okviru multidisciplinarnog istraživačkog tima nezavisni stručnjaci motre sadržaj potencijalno štetnih tvari i prate utjecaje na sve sastavnice ekosustava.

U ovom radu prikazane su vrijednosti ukupnog sumpora izmjerenog u tlu (u periodu od jeseni 2006. do proljeća 2010.) i u biljci (u periodu od proljeća 2000. do proljeća 2010.) te koncentracije plinovitih sumporovih spojeva u zraku. Koncentracije sumporovodika $\left(\mathrm{H}_{2} \mathrm{~S}\right)$ i merkaptana $(\mathrm{RSH})$ mjerene su u razdoblju ljeto 2002-jesen 2010, dok su koncentracije sumporova(IV) oksida $\left(\mathrm{SO}_{2}\right.$ ) određivane u razdoblju proljeće 2008-jesen 2010. Prikazane su i godišnje vrijednosti ukupne atmosferske depozicije sumpora $\left(\mathrm{S}_{-} \mathrm{SO}_{4}\right)$ izmjerene na mjernoj stanici Bilogora (za period od 2001. do 2010.).

Srednje mjesečne koncentracije $\mathrm{H}_{2} \mathrm{~S}$ u zraku kretale su se između $0,2 \mu \mathrm{g} \mathrm{m}^{-3}$ i 2,0 $\mu \mathrm{g} \mathrm{m}^{-3}$, merkaptana između $0,1 \mu \mathrm{g} \mathrm{m}^{-3}$ i $24,5 \mu \mathrm{g} \mathrm{m}^{-3}$ te $\mathrm{SO}_{2}$ između $0,4 \mu \mathrm{g} \mathrm{m}^{-3}$ i $2,8 \mu \mathrm{g} \mathrm{m}^{-3}$, ovisno o lokaciji i sezoni uzorkovanja. Srednje vrijednosti ukupnog sumpora u tlu i u trpucu kretale su se redom od $610 \mathrm{mg} \mathrm{kg}^{-1}$ do $1599 \mathrm{mg}$ $\mathrm{kg}^{-1}$ te od $3614 \mathrm{mg} \mathrm{kg}^{-1}$ do $4342 \mathrm{mg} \mathrm{kg}^{-1}$, ovisno o tipu tla, lokaciji i dubini uzorkovanja, dok su prosječne vrijednosti masenog udjela ukupnog sumpora, za cijeli period istraživanja, za tlo, iznosile $1080 \mathrm{mg} \mathrm{kg}^{-1}$ $(\mathrm{n}=80)$ za obje ispitivane dubine te $4108 \mathrm{mg} \mathrm{kg}^{-1} \mathrm{za}$ sve ispitivane uzorke trpuca $(\mathrm{n}=85)$.

Prosječno godišnje ukupno atmosfersko taloženje sumpora na mjernoj stanici Bilogora iznosilo je $6,3 \mathrm{~kg}$ $\mathrm{ha}^{-1} \mathrm{~S}_{-} \mathrm{SO}_{4}$

KLJUČNE RIJEČI: depozicija, $\mathrm{H}_{2} \mathrm{~S}$, merkaptani, Plantago lanceolata, $\mathrm{SO}_{2}$, tlo, ukupni sumpor, zrak

\section{CORRESPONDING AUTHOR:}

Željka Zgorelec

Faculty of Agriculture, University of Zagreb

Svetošimunska cesta 25, 10000 Zagreb, Croatia

E-mail:zzgorelec@agr.hr 